\title{
Prognostic significance of tumor-associated macrophages in breast cancer: a meta-analysis of the literature
}

\author{
Xixi Zhao ${ }^{1, *}$, Jingkun Qu ${ }^{2, *}$, Yuchen Sun ${ }^{3}$, Jizhao Wang ${ }^{2}$, Xu Liu ${ }^{2}$, Feidi Wang ${ }^{1}$, Hong \\ Zhang ${ }^{1}$, Wen Wang ${ }^{1}$, Xingcong $\mathrm{Ma}^{1}{ }^{1}$, Xiaoyan $\mathrm{Gao}^{1}$ and Shuqun Zhang ${ }^{1}$ \\ ${ }^{1}$ Department of Oncology, The Second Affiliated Hospital of Xi'an Jiaotong University, Xi'an, Shaanxi, P.R. China \\ ${ }^{2}$ The Second Department of Thoracic Surgery, The First Affiliated Hospital of Xi'an Jiaotong University, Xi'an, Shaanxi, P.R. \\ China \\ ${ }^{3}$ The Department of Radiation Oncology, The First Affiliated Hospital of Xi'an Jiao Tong University, Xi'an, Shaanxi, P.R. China \\ * These authors have contributed equally to this work \\ Correspondence to: Shuqun Zhang, email: zhangshuqun1971@aliyun.com
}

Keywords: breast cancer, tumor associated macrophages, prognosis, meta-analysis

Received: September 12, $2016 \quad$ Accepted: February 06, 2017

Published: February 25, 2017

Copyright: Zhao et al. This is an open-access article distributed under the terms of the Creative Commons Attribution License (CC-BY), which permits unrestricted use, distribution, and reproduction in any medium, provided the original author and source are credited.

\section{ABSTRACT}

Purpose: Tumor associated macrophages (TAMs) are important prognostic factors and have been proved to be associated with the invasion and migration of various cancer. However, the relationship between TAMs and breast cancer outcomes remains unclear.

Experimental Design: Sixteen studies with a total of 4,541 breast cancer patients were included in this meta-analysis. Correlation of TAMs with overall survival (OS), disease-free survival(DFS), relapse-free survival (RFS), breast cancer special survival (BCSS) and clinicopathological features were analyzed. Survival data and clinicopathological value were integrated by analyzing hazard ratio(HR) and odds ratio(OR) separately and using Fixed-effect or Random-effect model according to heterogeneity. All statistical tests were two-sided.

Results: OS and DFS were correlated with high density of TAMs with HR= $1.504(1.200,1.884) / 2.228(1.716,2.892)$ respectively. And subgroup analysis of location and biomarker in OS and DFS group showed prognosis was associated with TAMs distribution and biomarker selection. Besides, TAMs high infiltration was significantly related to age, size, histologic grade, ER/PR status, basal phenotype and vascular invasion.

Conclusion: High density of TAMs was associated with poor survival rates of breast cancer. TAMs in stroma are associated with worse outcome than that in nest and using CD68 as a biomarker for TAMs to evaluate the risk is better than CD163 or CD206 alone. Moreover, high infiltration of TAMs was significantly associated with negative hormone receptor status and malignant phenotype. TAMs infiltration can serve as a novel prognostic factor in breast cancer patients.

\section{INTRODUCTION}

Breast cancer is the most frequent cancer in female. In recent years, with the trend of younger age and increasing morbidity, it threatens the health of women seriously, but the mechanism isn't clear $[1,2]$. Breast cancer has obvious heterogeneity on molecular phenotype, tissue pathology and clinical characteristics. Nowadays, the focus of treatment strategy is using chemotherapy to induce tumor cell apoptosis, resistance to hormone receptor and targeted therapy. Meanwhile, growing evidence has demonstrated the important role of tumor microenvironment in the development of cancer and the treatment aim at interfering the microenvironment and metabolism stimulation has gained clinical utility [3-5] 
Macrophage is a main kind of immune cell infiltrating to tumor microenvironment and it can change its phenotype according to the signal stimulation of microenvironment. TAMs are generally characterized by the expression of cell surface marker CD68 [6]. Macrophages can be divided into classically activated M1 and selectively activated M2 [7, 8]. M1 macrophages are induced by TLR (toll like receptor) and IFN- $\gamma$, expressing high level of CD86, CD40 and PD-L1 and play the role of pro-inflammatory and anti-tumor response [9]. While M2 is totally different, they are characterized by the expression of CD163, CD206, CD204 and arginase-1, secreting IL10 and TGF- $\beta$, expressing VEGF (vascular endothelial growth factor) and promoting both the activation of tumor related regulatory $\mathrm{T}$ cells and matrix formation, all of which promote tumor progression [10-12].

Plentiful studies have confirmed that TAMs are associated with poor outcome of human cancer, such as hepatoma, gastric cancer, lung cancer and so on [13-16]. However, other studies have opposite reports [17]. Studies reveal that macrophage subtype, location, density are all in correlation with cancer survival $[18,19]$. For breast cancer, studies have shown that density of TAMs is related to hormone receptor status, stage, lymph node metastasis and poor prognosis [2, 18-21]. However, further studies are needed to clarify the influence of TAMs including the role of intratumoral distribution and surface marker selection. Therefore, we conducted a detailed metaanalysis summarizing the related evidence to evaluate the prognostic value of TAMs in human breast cancer.

\section{RESULTS}

\section{Search results and study characteristics}

Literature retrieval yield 3148 records and we selected 58 candidate studies (Figure 1). By further screening, 42 articles are excluded because of lacking survival data and canine tissue samples. Finally, 16 citations with valid survival data were included.

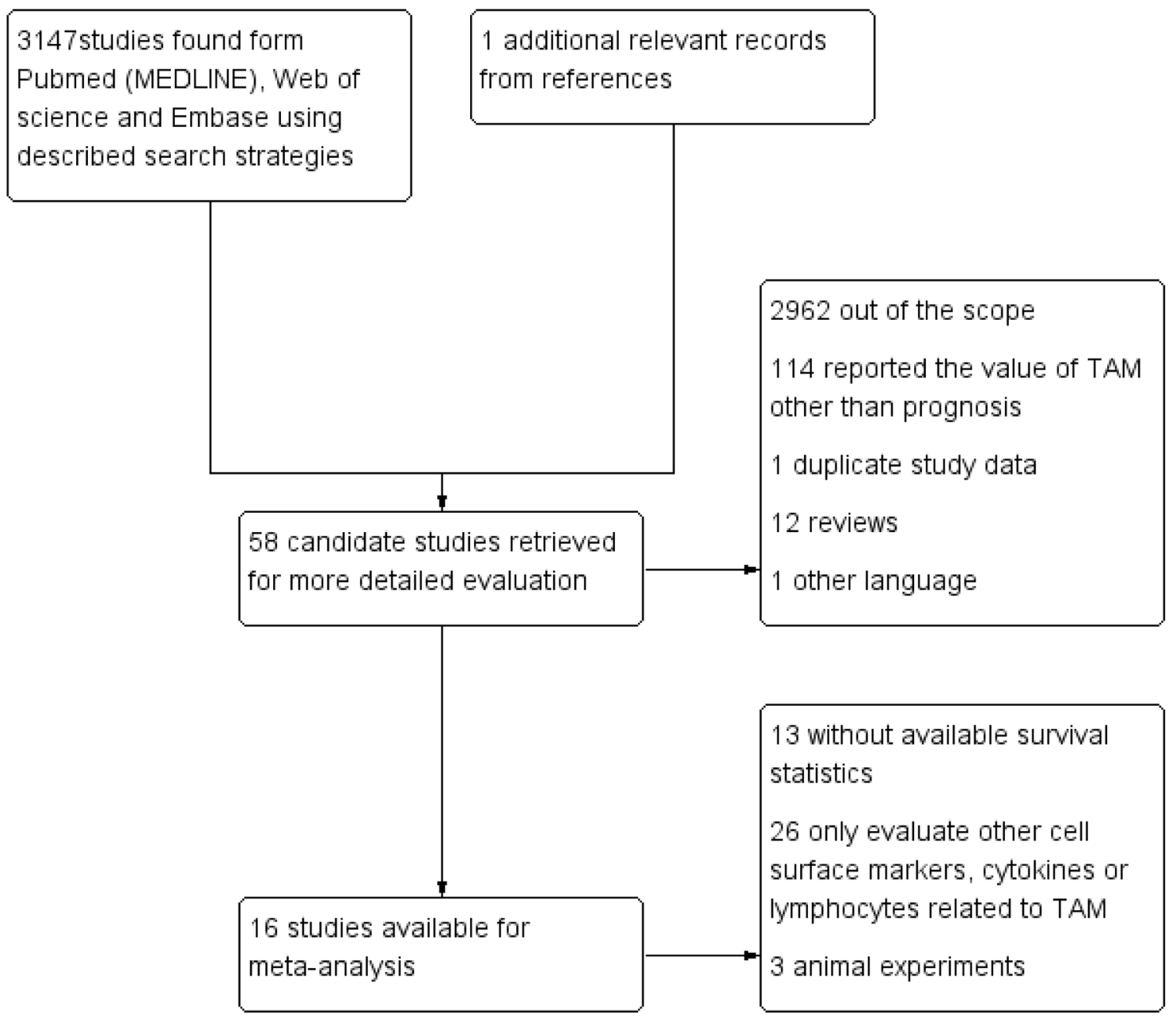

Figure 1: Selection of studies. Flow chart showed the selection process of the included studies. 
Table 1: Characteristics of the eligible studies.

\begin{tabular}{|c|c|c|c|c|c|c|c|c|c|c|c|c|}
\hline Ref & $\begin{array}{l}\text { Patient } \\
\text { No. }\end{array}$ & $\begin{array}{l}\text { Age } \\
\text { median } \\
\text { (range) }\end{array}$ & $\begin{array}{l}\text { Follow-up } \\
\text { median } \\
\text { (range) }\end{array}$ & Cutoff value & $\begin{array}{l}\text { Macrophage } \\
\text { density }\end{array}$ & $\begin{array}{l}\text { Tissue } \\
\text { distribution }\end{array}$ & Analysis & Marker & Company & Stage & $\begin{array}{l}\text { NOS } \\
\text { Score }\end{array}$ & Result \\
\hline $\begin{array}{l}\text { Koru-Sengul,T. } \\
(2016)\end{array}$ & 150 & $54.9 \pm 12.4$ & $116(2-326)$ & $\begin{array}{ll}1+=1-150 & \text { cells } / \mathrm{mm}^{2} \\
2+=151-300 & \text { cells } / \mathrm{mm}^{2} \\
3+=>300 & \text { cells } / \mathrm{mm}^{2} \\
\text { CD163/CD206 } 2+/ 3+\mathrm{vs} \\
1+\text { CD40 } 1+/ 2+\text { vs } 0\end{array}$ & cells $/ \mathrm{mm}^{2}$ & $\begin{array}{l}\text { tumor nest and } \\
\text { stroma }\end{array}$ & $\begin{array}{l}\text { blind and } \\
\text { independent }\end{array}$ & $\begin{array}{l}\text { CD163 } \\
\text { CD206 } \\
\text { CD40 }\end{array}$ & $\begin{array}{l}\text { CD163/206/40 } \\
\text { R\&D,Minneapolis }\end{array}$ & I-IV & 8 & OS \\
\hline Yang, J. (2015) & 100 & $55(28-80)$ & 60 & $\begin{array}{l}>61.14 \pm 23.76 \\
<61.14 \pm 23.76\end{array}$ & $\begin{array}{l}\text { high-power } \\
\text { field(HFP) }\end{array}$ & $\begin{array}{l}\text { tumor nest } \\
\text { and stroma } / \\
\text { peritumoral } \\
\text { stroma }\end{array}$ & no & CD68 & DAKO, Carpinteria, CA & I-IV & 6 & os \\
\hline Sousa, S. (2015) & 562 & $\begin{array}{l}52.5 \\
65)\end{array}$ & $\begin{array}{l}35 \\
43.6)\end{array}$ & $>369 ; \leq 369$ & cells $/ \mathrm{mm}^{2}$ & $\begin{array}{l}\text { tumor mest and } \\
\text { stroma }\end{array}$ & $\begin{array}{l}\text { double- } \\
\text { blinded } \\
\text { fashion }\end{array}$ & $\begin{array}{l}\text { CD68 } \\
\text { CD163 }\end{array}$ & $\begin{array}{l}\text { CD68(Abcam,CambridgeUK } \\
\text { );CD163( Novocastra, New- } \\
\text { castle,UK) }\end{array}$ & I-IV & 8 & RFS \\
\hline Gwak,J.M. (2015) & 372 & $\begin{array}{l}50.96(26- \\
87)\end{array}$ & $\begin{array}{l}92.4 \\
127.2)\end{array}$ & $\begin{array}{l}\text { intratumoral: }>24.2 ; \leq 24.2 \\
\text { stromal: }>35.3 ; \leq 35.3\end{array}$ & $\begin{array}{l}\text { high-power } \\
\text { field(HPF) }\end{array}$ & $\begin{array}{l}\text { tumor nest vs } \\
\text { stroma }\end{array}$ & no & CD68 & Dako, Carpinteria, CA & I-III & 7 & DFS \\
\hline $\begin{array}{l}\text { Satu } \\
(2015)\end{array}$ & 278 & $59(32-86)$ & $\begin{array}{r}75.6 \\
133.2)\end{array}$ & $\begin{array}{l}\text { CD163:>26; } \leq 26 \\
\text { CD68: }>34 ; \leq 34\end{array}$ & $\begin{array}{l}\text { high-power } \\
\text { field(HPF) }\end{array}$ & $\begin{array}{l}\text { tumor nest and } \\
\text { stroma }\end{array}$ & $\begin{array}{l}\text { blind and } \\
\text { independent }\end{array}$ & $\begin{array}{l}\text { CD163 } \\
\text { CD68 }\end{array}$ & Thermo Scientific & I-III & 8 & OS \\
\hline Yuan,Z.Y. (2014) & 287 & NA & $89(4-181)$ & $>16 ; \leq 16$ & $\begin{array}{l}\text { high-power } \\
\text { field(HPF) }\end{array}$ & stroma & no & CD68 & $\begin{array}{l}\text { Thermo Fisher Scientific, } \\
\text { Waltham, MA, USA }\end{array}$ & I-III & 7 & $\begin{array}{l}\text { OS/ } \\
\text { DFS }\end{array}$ \\
\hline Zhang,Y. (2013) & 172 & $49(29-73)$ & 60 & $\begin{array}{l}\geq 26 / \text { tissue cores }<26 / / \\
\text { tissue cores }\end{array}$ & $\begin{array}{l}\text { high-power } \\
\text { field(HPF) }\end{array}$ & stroma & blind & CD68 & Abcam, USA & I-IV & 7 & $\begin{array}{l}\text { OS/ } \\
\text { DFS }\end{array}$ \\
\hline Carrio,R. (2013) & 29 & $59(32-87)$ & $\begin{array}{l}138 \\
292)\end{array}$ & $\begin{array}{l}\geq 5 \quad \text { TAMs/slide; } \quad<5 \\
\text { TAMs/slide }\end{array}$ & $\begin{array}{l}\text { high-power } \\
\text { field(HPF) }\end{array}$ & tumor nest & blind & CD68 & Carpinteria, CA, USA & I & 7 & OS \\
\hline $\begin{array}{l}\text { Campbell,M.J } \\
(2013)\end{array}$ & 102 & NA & 100 & $>24 ; \leq 24$ & $\begin{array}{l}\text { high-power } \\
\text { field(HPF) }\end{array}$ & $\begin{array}{l}\text { tumor nest and } \\
\text { stroma }\end{array}$ & no & $\begin{array}{l}\text { CD68+/ } \\
\text { PCNA }+\end{array}$ & Dako, Cambridgeshire, UK & I-III & 7 & RFS \\
\hline $\begin{array}{l}\text { Mohammed,Z.M. } \\
\text { (2012) }\end{array}$ & 468 & NA & 165 & $\geq 3 \% ;<3 \%$ & $\begin{array}{l}\text { high-power } \\
\text { field(HPF) }\end{array}$ & $\begin{array}{l}\text { tumor nest and } \\
\text { stroma }\end{array}$ & $\begin{array}{l}\text { blind and } \\
\text { independent }\end{array}$ & CD68 & Dako, Glostrup, Denmark & I-III & 8 & RFS \\
\hline Medrek, C. (2012) & 144 & $65(34-97)$ & $\begin{array}{l}78.6 \\
90.6)\end{array}$ & $\begin{array}{l}\text { absent/sparse (0-2) } \\
\text { dense (3) }\end{array}$ & $\begin{array}{l}\text { high-power } \\
\text { field (HPF) }\end{array}$ & $\begin{array}{l}\text { tumor nest vs } \\
\text { stroma }\end{array}$ & no & $\begin{array}{l}\text { CD68 } \\
\text { CD163 }\end{array}$ & $\begin{array}{lll}\text { CD163 } & \text { Novocastra } & \text { CD68 } \\
\text { DAKO } & & \end{array}$ & I-III & 8 & $\begin{array}{l}\text { OS/ } \\
\text { RFS/ } \\
\text { BCSS }\end{array}$ \\
\hline $\begin{array}{l}\text { Mahmoud,S.M. } \\
(2012)\end{array}$ & 1322 & $<70$ & $127(1-192)$ & $\begin{array}{l}\text { intratumoral: }>6 ; \leq 6 \\
\text { stromal: }>17 ; \leq 17\end{array}$ & $\begin{array}{l}\text { high-power } \\
\text { field(HPF) }\end{array}$ & $\begin{array}{l}\text { tumor nest and } \\
\text { stroma }\end{array}$ & blind & CD68 & Dako, Glostrup,Denmark & I-III & 6 & BCSS \\
\hline $\begin{array}{l}\text { Campbell,M.J } \\
(2011)\end{array}$ & 216 & 55.75 & 108 & $>5 ; \leq 5$ & $\begin{array}{l}\text { high-power } \\
\text { field(HPF) }\end{array}$ & $\begin{array}{l}\text { tumor nest and } \\
\text { stroma }\end{array}$ & no & $\begin{array}{l}\text { CD68+ } \\
\text { PCNA }+\end{array}$ & Dako, Cambridgeshire, UK & I-III & 8 & $\begin{array}{l}\text { OS/ } \\
\text { RFS }\end{array}$ \\
\hline $\begin{array}{l}\text { Mukhtar,R.A. } \\
\text { (2011) }\end{array}$ & 70 & $50(30-74)$ & $\begin{array}{l}87.6 \\
156)\end{array}$ & $>38.5 ; \leq 38.5$ & $\begin{array}{l}\text { high-power } \\
\text { field(HPF) }\end{array}$ & $\begin{array}{l}\text { tumor nest and } \\
\text { stroma }\end{array}$ & $\begin{array}{l}\text { blind and } \\
\text { independent }\end{array}$ & $\begin{array}{l}\text { CD68+l } \\
\text { PCNA+ }+\end{array}$ & Dako, Cambridgeshire, UK & I-III & 8 & OS \\
\hline Murri,A.M. (2008) & 168 & $\begin{array}{l}>50 \\
(81 \%)\end{array}$ & 72 & NA & NA & $\begin{array}{l}\text { tumor and } \\
\text { surrounding } \\
\text { stroma }\end{array}$ & $\begin{array}{l}\text { blind and } \\
\text { independent }\end{array}$ & CD68 & Dako, Cambridgeshire, UK & I-III & 7 & $\begin{array}{l}\text { BCSS } \\
\text { /OS }\end{array}$ \\
\hline Leek,R.D. (1996) & 101 & NA & 60 & $>12 ; \leq 12$ & $\begin{array}{l}\text { high-power } \\
\text { field(HPF) }\end{array}$ & $\begin{array}{l}\text { tumor nest and } \\
\text { stroma }\end{array}$ & no & CD68 & Dako, Cambridgeshire, UK & NA & 6 & RFS \\
\hline
\end{tabular}

Abbreviations: NA: Not available; OS: overall survival; DFS: disease-free survival; RFS: relapse-free survival; BCSS: breast cancer specific survival; NOS: Newcastle-Ottawa Scale checklist. 
The characteristics of included study containing OS, DFS, RFS, BCSS data were listed in Table 1. There are 4541 patients in total of included studies. And the sample size for OS, DFS, RFS, BCSS was 1699, 916, 1593, 1634 separately. All the studies used IHC staining in formalinfixed paraffin-embedded tissue blocks to evaluate TAMs biomarker expression. When evaluating TAM density, $50 \%$ studies performed blinded and independent reading.
Cut-off value for definition of TAMs density low versus high could be retrieved from 15 articles (Table1).

\section{TAMs definition and density}

The introduction of the antibodies and definition method of TAMs of included studies were shown in Table

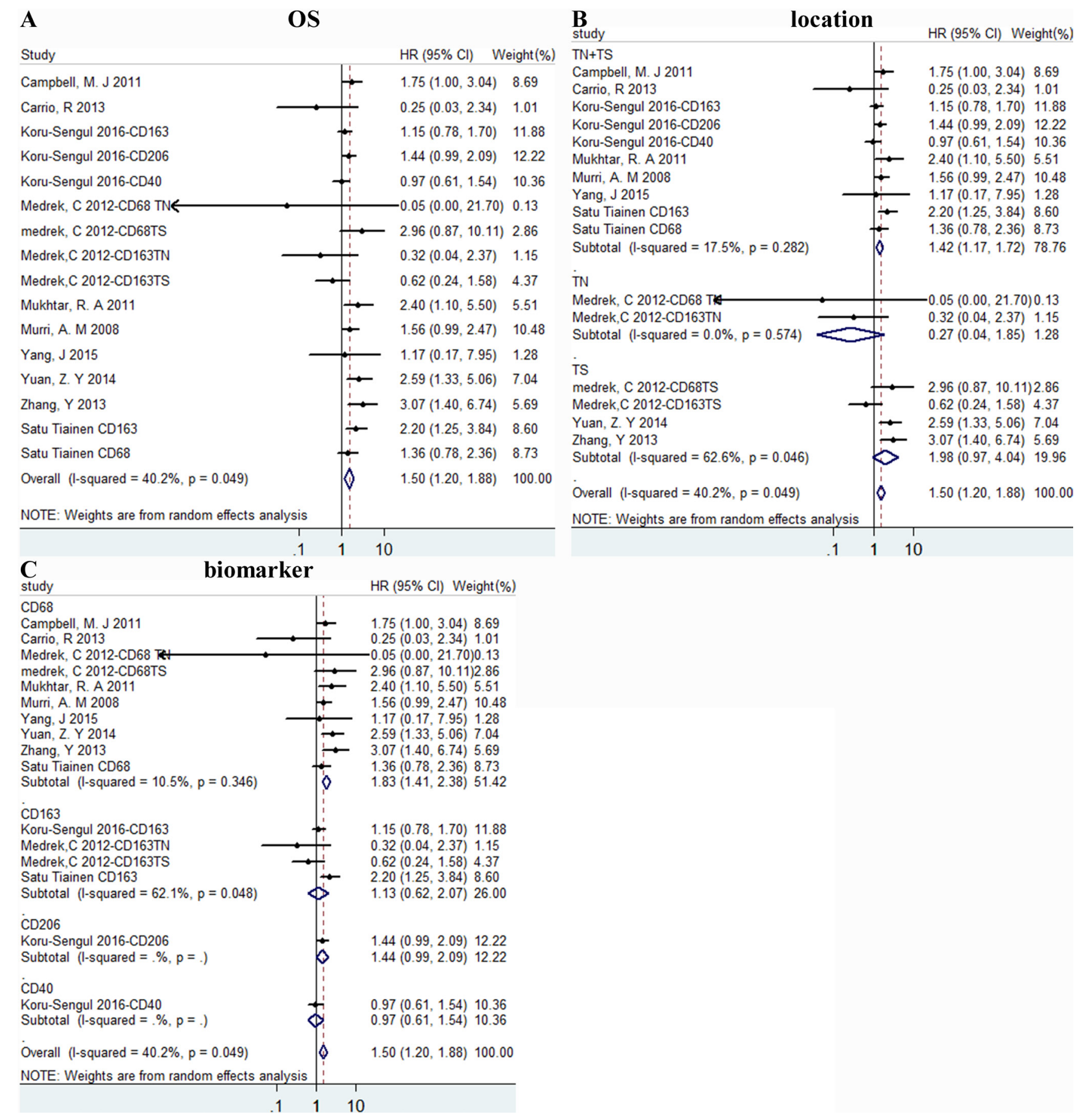

Figure 2: The forest plots of HRs for OS. Forest plots and meta-analysis of studies evaluating HRs of high TAM counts as compared to low counts. Survival data were reported as OS A., as well as subgroup analysis of location B. and biomarker $\mathbf{C}$. among included studies. TN: tumor nest; TS: tumor stroma. 
Table 2: Meta-analysis for the association of increased total TAMs expression and clinicopathological features of breast cancer patients

\begin{tabular}{|c|c|c|c|c|c|c|c|c|}
\hline Clinicopathological features & \begin{tabular}{|l|}
$\begin{array}{l}\text { No.of } \\
\text { studies }\end{array}$ \\
\end{tabular} & \begin{tabular}{|l|}
$\begin{array}{l}\text { No.of } \\
\text { patients }\end{array}$ \\
\end{tabular} & Model & OR(95\% CI) & $P$-Value & Heterogeneity & & \\
\hline & & & & & & $I^{2}$ & $I^{2}(\%)$ & $P$-Value \\
\hline $\operatorname{Age}(\leq 50$ vs. $>50)$ & 6 & 2708 & Fixed & $1.211(1.031,1.422)$ & 0.02 & 3.45 & 0 & 0.63 \\
\hline $\operatorname{Size}(\leq 2 \mathrm{~cm}$ vs. $>2 \mathrm{~cm})$ & 6 & 2698 & Fixed & $0.73(0.616,0.865)$ & 0 & 7.41 & 32.5 & 0.192 \\
\hline Histologic grade(G1-2 vs. G3) & 9 & 3141 & Random & $0.344(0.257,0.459)$ & 0 & 20.96 & 61.8 & 0.007 \\
\hline lymph node status(N0 vs. N1-3) & 6 & 2904 & Random & $0.843(0.646,1.099)$ & 0.206 & 13.71 & 48.9 & 0.057 \\
\hline ER status(Negative vs. Positive) & 7 & 2788 & Random & $2.760(1.808,4.213)$ & 0 & 31.74 & 77.9 & 0 \\
\hline PR status(Negative vs. Positive) & 5 & 2159 & Fixed & $2.188(1.825,2.623)$ & 0 & 4.59 & 0 & 0.468 \\
\hline HER-2(Negative vs. Positive) & 7 & 2558 & Random & $0.807(0.459,1.418)$ & 0.456 & 45.37 & 84.6 & 0 \\
\hline $\begin{array}{l}\text { Basal phenotype(Negative vs. } \\
\text { Positive) }\end{array}$ & 6 & 2268 & Fixed & $0.436(0.346,0.550)$ & 0 & 0.97 & 0 & 0.915 \\
\hline $\begin{array}{lll}\text { Vascular } & \text { invasion(Absent } & \text { vs. } \\
\text { Present) } & & \\
\end{array}$ & 3 & 1869 & Fixed & $0.623(0.509,0.763)$ & 0 & 3.14 & 36.4 & 0.208 \\
\hline
\end{tabular}

1. 15 studies used CD68, 4 studies used CD163 and only one study used CD206 and CD40. Of all the studies using CD68, 18.75\% using CD68+/PCNA+.

\section{Data synthesis: clinicopathological features}

Our results showed that high TAMs infiltration were significantly correlated to age $(\mathrm{OR}=1.211(1.031,1.422)$, fixed-effect model), size $(\mathrm{OR}=0.73(0.616,0.865)$, fixed-effect model), histologic grade $(\mathrm{OR}=0.344(0.257$, 0.459), random-effect model $)$, ER status $(\mathrm{OR}=2.760$ $(1.808,4.213)$, random-effect model), PR status (OR = $2.188(1.825,2.623)$, fixed-effect model), basal phenotype $(\mathrm{OR}=0.436(0.346,0.550)$, fixed-effect model $)$, vascular invasion $(\mathrm{OR}=0.623(0.509,0.763)$, fixed-effect model $)$. On the contrary, high TAMs infiltration was not found to be associated with lymph node status $(\mathrm{OR}=0.843(0.646$, 1.099), random-effect model), HER-2 status ( $\mathrm{OR}=0.807$ $(0.459,1.418)$, random-effect model). These results indicated that breast cancer with high TAMs infiltration exhibited aggressive biological behaviors (Table 2).

\section{Data synthesis: overall survival}

High density of TAMs was associated with poor OS, HR $=1.504(1.200,1.884), \mathrm{I}^{2}=40.2 \%$ (Figure 2A) Besides, the results of subgroup analysis according to location were 1.42 (1.17, 1.72), $0.27(0.04,1.85), 1.98$ $(0.97,4.04)$ of $\mathrm{TN}+\mathrm{TS}$ (tumor nest and stroma), TN (tumor nest) and TS (tumor stroma) group separately (Figure 2B). According to biomarker, HR $=1.83$ (1.41, 2.38)/1.13 (0.62, 2.07)/1.44 (0.99, 2.09)/0.97 (0.61, 1.54) of CD68, CD163, CD206, CD40 separately(Figure 2C).

\section{Data synthesis: disease free survival}

High density of TAMs was related to poor DFS, HR $=2.228(1.716,2.892), \mathrm{I}^{2}=0 \%($ Figure $3 \mathrm{~A})$. And results were associated with TN (tumor nest) and TS (tumor stroma) with $\mathrm{HR}=3.14(1.46,6.75) / 2.08(1.57,2.78)$ separately, $\mathrm{I}^{2}=0 \%$ (Figure $3 \mathrm{~B}$ ). And we also conducted a subgroup meta-analysis according to hormone status and results in all subgroups showed obvious significance (Figure 3C).

\section{Data synthesis: relapse free survival}

We didn't find relationship between TAMs density and RFS, with HR $=1.799(0.972,3.330), \mathrm{I}^{2}=82.5 \%$ (Figure 4A). Then subgroup analysis was conducted to find the origin of heterogeneity. According to location of TAMs, we divided our studies into three groups: TS, TN+TS, TN. However, because of different biomarker, hormone status within these studies, it's hard to eliminate heterogeneity (Figure 4B).

\section{Data synthesis: breast cancer special survival}

Results of high density of TAMs versus low showed no difference for BCSS, HR $=0.786(0.505,1.222)$, $\mathrm{I}^{2}$ $=68.6 \%$ (Figure 5A). Then we conducted subgroup analysis according to location and there was still no difference(Figure 5B).

\section{Publication bias}

We use funnel plot analysis and Egger'/Begg' test to evaluate publication bias and there was no statistical difference for OS, DFS, RFS and BCSS with P value 
of $0.574 / 0.787,0.019 / 0.293,0.368 / 0.805,0.314 /$ 0.322 separately. Begg's funnel plots with pseudo $95 \%$ confidence limits of the four groups were listed in Figure 6A-6D.

\section{Sensitivity analysis}

Results of removal of each study at a time could be seen in Figure 7A-7D. For the OS and DFS analysis, removal of each study didn't change HR significantly. For the RFS analysis, removal of "Mohammed,Z.M(ER-) 2012" had an important effect of the results. For BCSS, removal of "Mahmoud, SM 2012" also affect the overall results.

\section{DISCUSSION}

Mountains of studies have illustrated the role of TAMs in cancer initiation and progression $[2,4,22-$
24]. But the pertinence between TAMs and outcomes of breast cancer hasn't been illuminated. In our metaanalysis, we chose OS, DFS, RFS and BCSS to assess risk of high macrophage density. Moreover, we analyzed the correlation between clinicopathological features and TAMs infiltration and found high TAMs infiltration was related to both poor survival rates and malignant biological behavior.

Our meta-analysis of 16 studies with 4541 patients in total shown that high density of TAMs was related to worse OS and DFS. What's more, we found that the prognostic significance of TAMs was affected by different biomarker, TAMs location and ER receptor status. High density of TAMs was related to poor prognosis and subgroup analysis showed that CD68 was better than M2 specific marker CD163 and CD206 alone in predicting OS. And results of subgroup analysis of location shown both TN+TS and TS group signified worse OS, while there was no difference of TAMs in TN group. All the results indicated that CD68 and TAMs in tumor stroma were

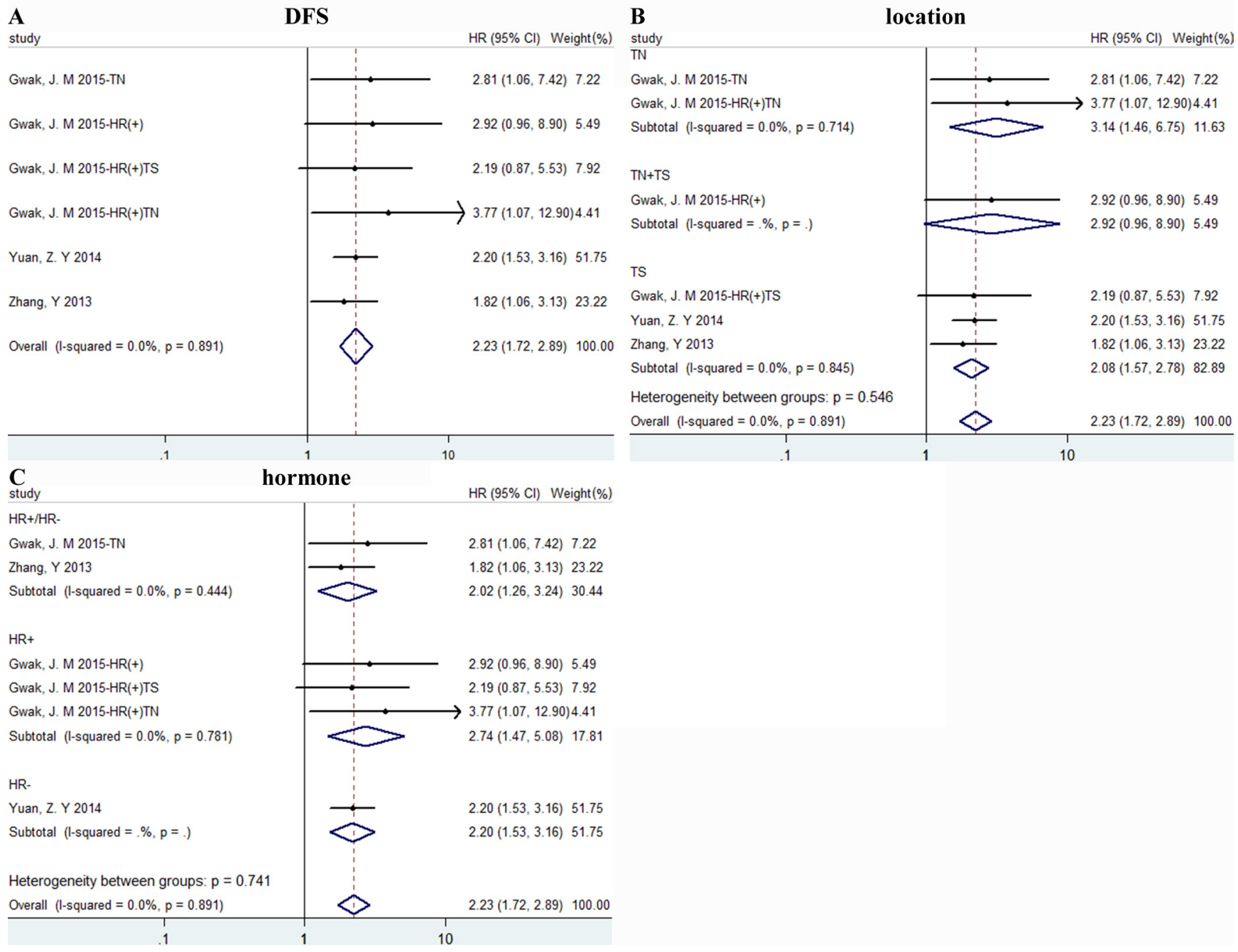

Figure 3: The forest plots of HRs for DFS. Forest plots and meta-analysis of studies evaluating HRs of high TAM counts as compared to low counts. Survival data were reported as DFS A., as well as subgroup analysis of the location B. and hormone status C. of included studies. TN: tumor nest; TS: tumor stroma. 
strongly associated with worse OS. For DFS, high density of TAMs had the similar prognostic significance as OS outcome.

Results of elevated TAMs of RFS shown no obvious correlation. And the sensitivity analysis shown the exclusion of study of "Mohammed,Z.M(ER-) 2012" obviously affect the association between TAMs density and RFS. This article mentioned above reported an improved recurrence-free survival of CD68 TAMs in ERbreast cancer, which was opposite to some other studies [25-27]. With regard to BCSS, results showed no statistical significance, $\mathrm{HR}=0.95(0.79,1.13)$. So far, the reasons for such discrepancies using similar methodology are unclear, however, some evidence declares macrophage markers, such as CD68 may be expressed by other non-myeloid tissues in cancer [28]. Besides, the heterogeneity of RFS and BCSS is considerable, maybe the results should be considered cautiously.

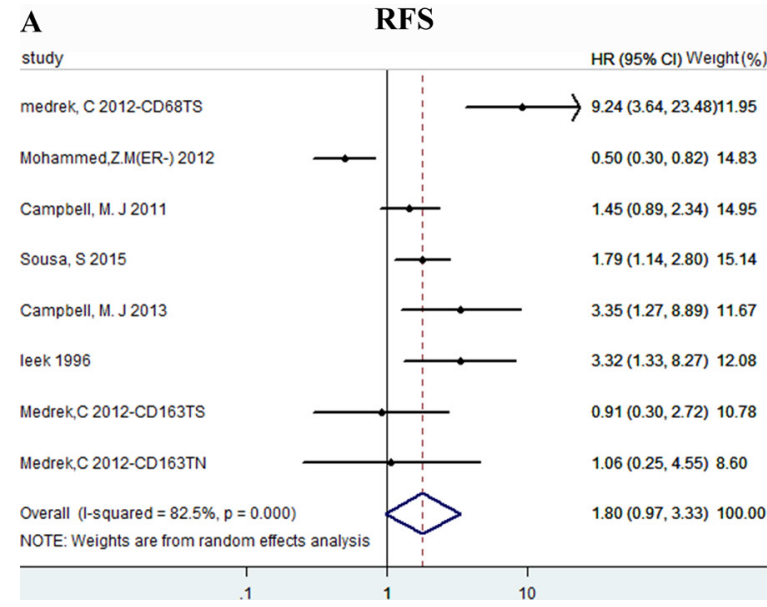

Furthermore, we analyzed association between TAMs infiltration and several clinicopathological parameters. Results indicated high density of TAMs was related to younger age, larger size, high histologic grade, negative hormone receptor status, malignant phenotype and vascular invasion, which were all crucial factors for predicting the prognosis. Thus, high density of TAMs may lead to poor survival rates by promoting tumor proliferation, migration and invasion.

This study has some important implications in breast cancer. Firstly, it demonstrates high TAMs are related to worse outcome, which indicates that TAMs may be a potential therapeutic target. Secondly, it shows the tissue distribution and CD68 biomarker of TAMs has an important role in prognostic prediction.

There are also limitations in this meta-analysis. First of all, the markers and cut-off values for assessing TAMs expression of individual studies are inconsistent and

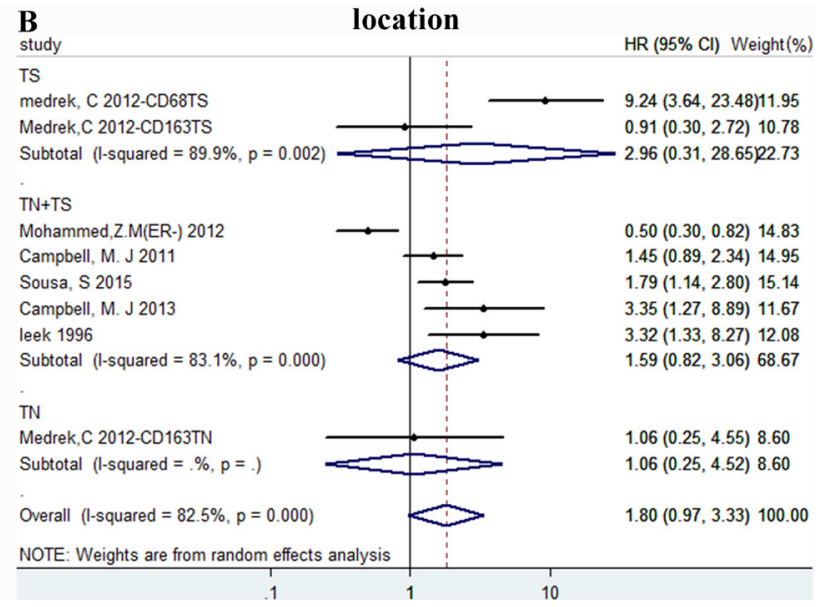

Figure 4: The forest plots of HRs for RFS. Forest plots and meta-analysis of studies evaluating HRs of high TAM counts as compared to low counts. Survival data were reported as RFS A., as well as subgroup analysis of the location B. Abbreviations: TN: tumor nest; TS: tumor stroma.
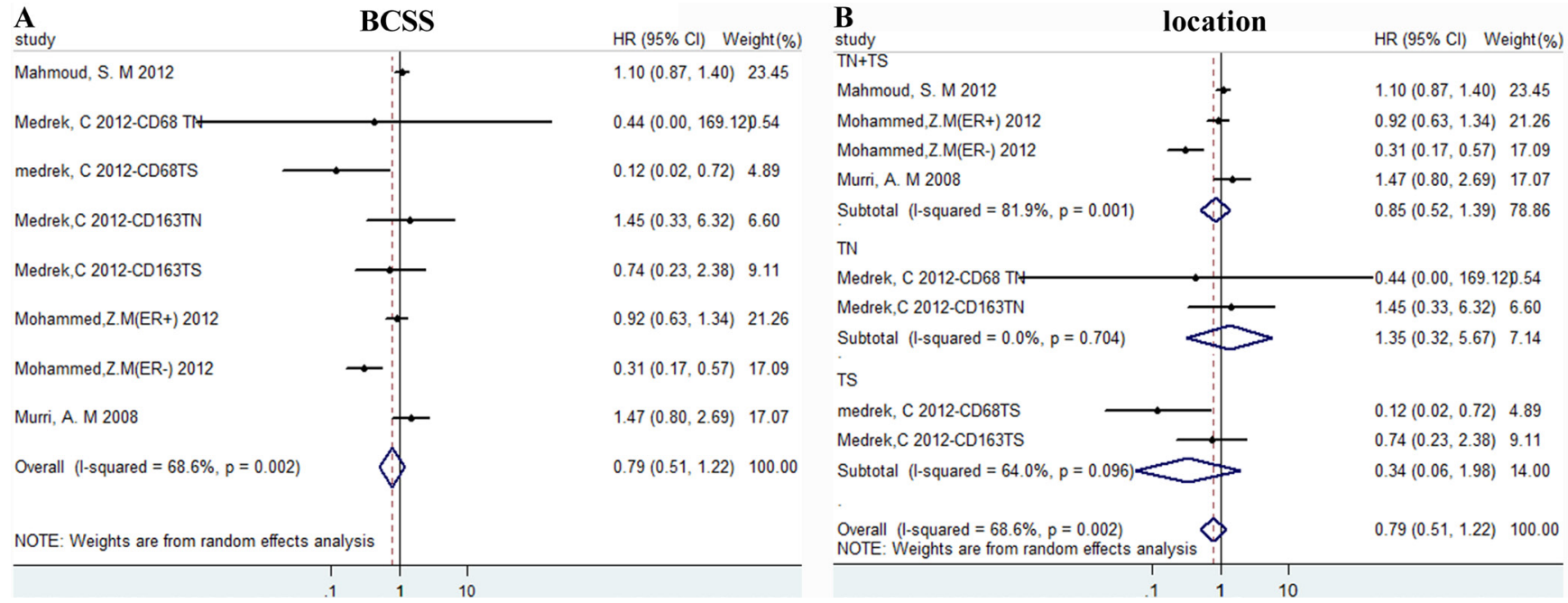

Figure 5: The forest plots of HRs for BCSS. Forest plots and meta-analysis of studies evaluating HRs of high TAM counts as compared to low counts. Survival data were reported as BCSS A., as well as subgroup analysis of the location B. Abbreviations: TN: tumor nest; TS: tumor stroma. 


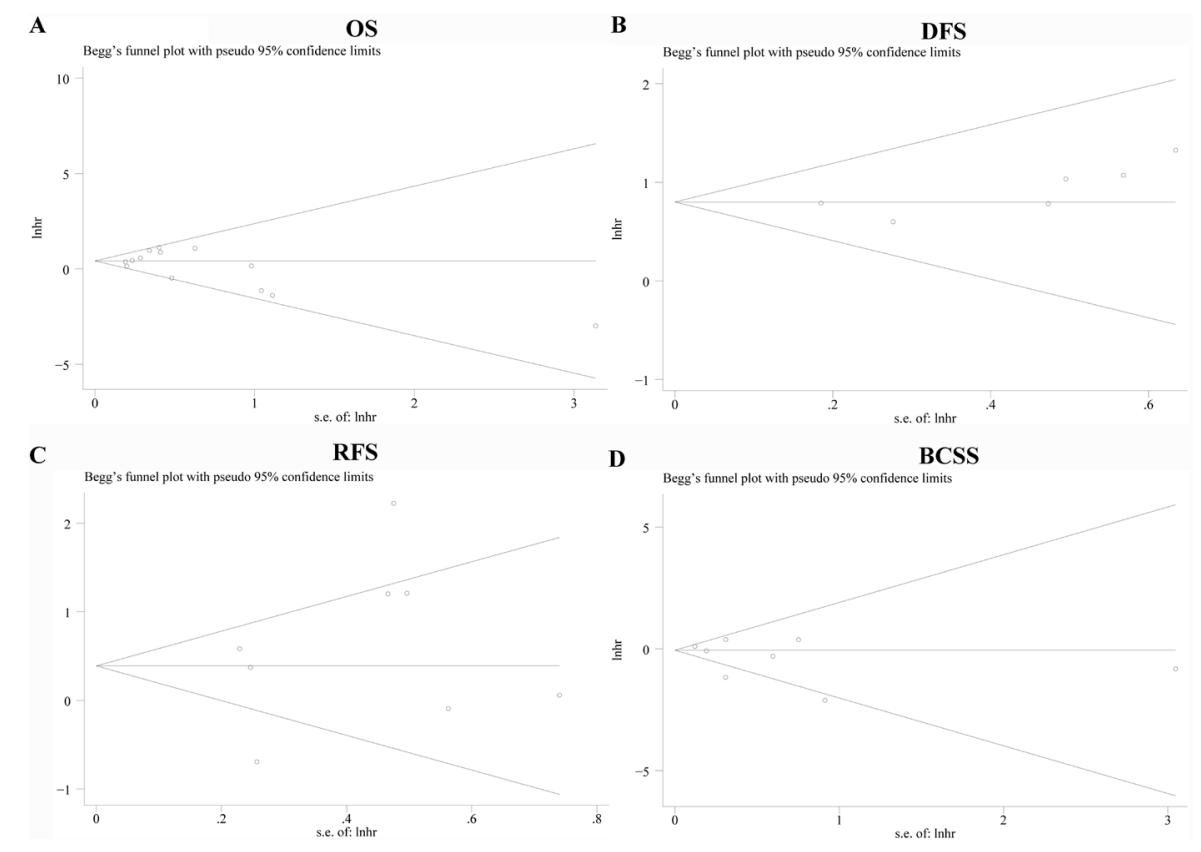

Figure 6: Funnel graph for assessment of potential publication bias in studies of TAM density in patients with breast cancer. Publication bias of OS A., DFS B., RFS C., BCSS D. of the meta-analysis showed no statistical significance $(p>0.05)$ using Begg's test.

\section{A OS}

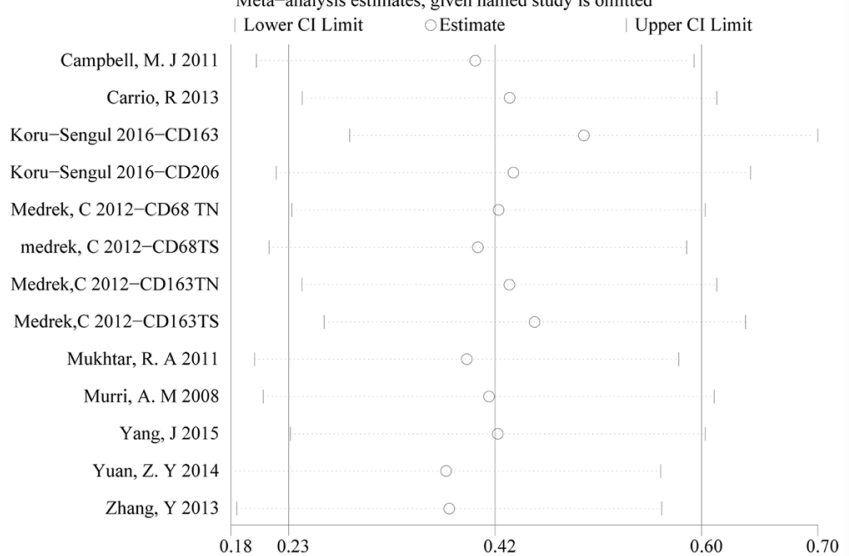

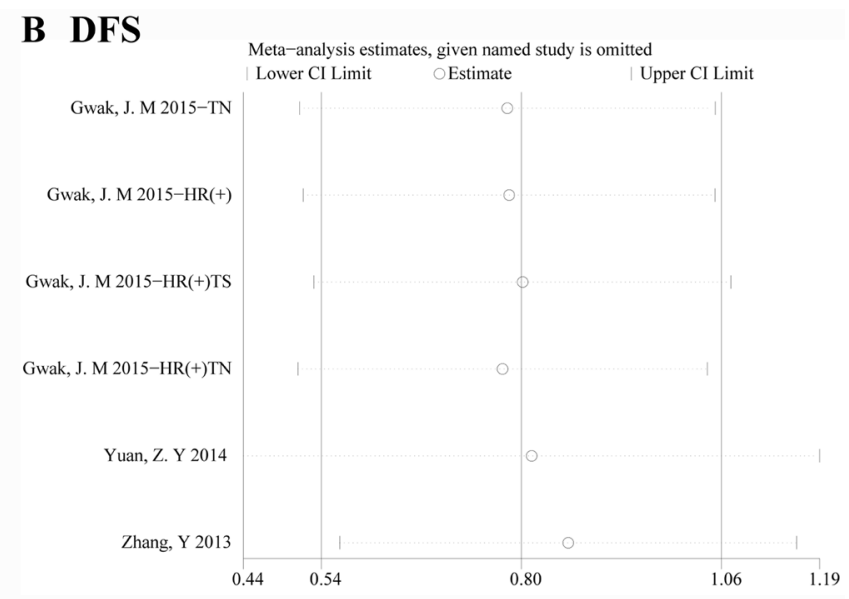

\section{BCSS}

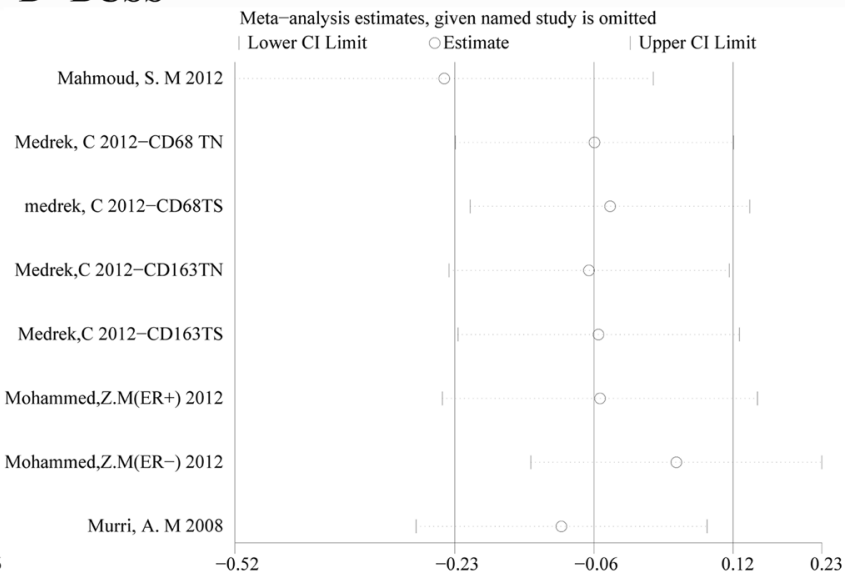

\section{RFS}

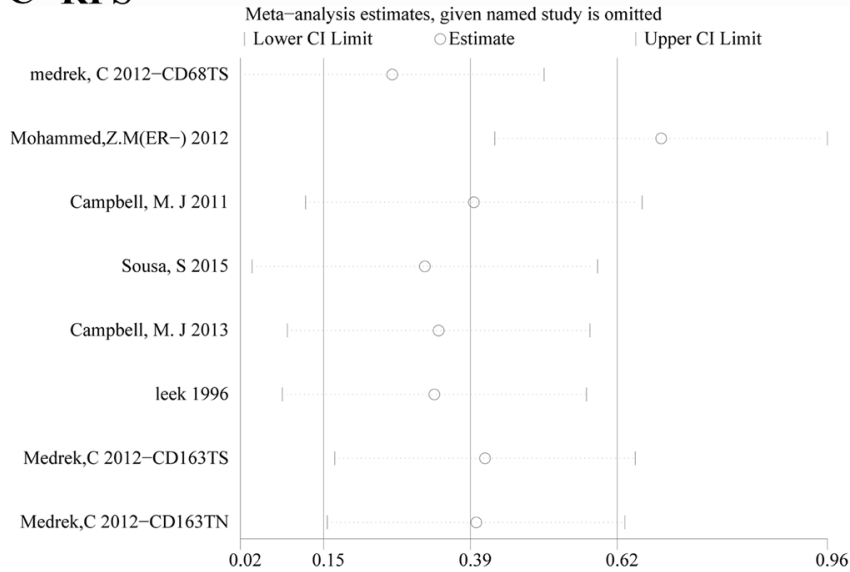

Figure 7: Sensitivity for included studies. The effect of single study was evaluated on the whole results of OS A., DFS B., RFS C., BCSS D. in this meta-analysis. 
cut-off value may be a source of considerable interstudy heterogeneity. Besides, although Begg's and Egger's test were performed and there was no statistical significance. Results should be interpreted cautiously because we only include studies with available HR value or K-M survival curves with necessary data.

In short, our analyses show that high density of TAMs in breast cancer tissues, especially CD68+ TAMs in tumor stroma, is associated with worse prognosis in human breast cancer. As main kind infiltrating cells in tumor microenvironment, TAMs have a close relationship with tumor cells by direct or indirect function [29]. Some factors secreted by TAMs also been reported to be correlated with poor prognosis $[30,31]$. Targeted therapies directly targeting TAMs, or reprogramming TAMs to M1phenotype could be promising in improving survival rates of breast cancer patients.

\section{MATERIALS AND METHODS}

\section{Search strategy}

This meta-analysis was conducted according to PRISMA guidelines. We searched PubMed (MEDLINE), Web of science and Embase from their inception until July 1, 2016 and the records and results are shown in Figure 1. The following Mesh Terms or key words were used in the search: "cancer", "tumor", "neoplasm", "carcinoma", "macrophages" and "breast cancer". The language was restricted to English. The references from identified articles were manually searched for additional relevant records.

\section{Inclusion criteria}

Inclusion criteria for primary studies were as follows:(1) proven diagnosis of breast cancer by pathology ; (2) without previous cancer history; (3) evaluating TAMs by CD68, CD206, CD163 using immunochemistry; (4) reporting the correlation of TAMs with OS, DFS, RFS, BCSS and clinicopathological features; (5) full-text studies published in English. Only articles conforming to all the five conditions above were selected, or they would be excluded. Two authors (ZXX and QJK) independently extracted all data. If there were disagreements, we solved by reaching a consensus or discussion with a third investigator. The names of authors and the medical centers involved were examined in each publication to avoid repeated data. The quality of included studies was assessed by using the Newcastle-Ottawa Scale checklist (NOS).

\section{Statistical analyses}

Included studies were divided into four groups for analysis: OS, DFS, RFS and BCSS. To integrate survival results, data of TAMs density of survival in individual study was extracted by estimating HRs and 95\% confidence interval values. Firstly, we searched original article to get HRs and 95\% CI. If data were only available in the form of figures, we read KaplanMeier curves by Engauge Digitizer version 4.1 (free software downloaded from http://sourceforge.net) and extracted survival data HRs and 95\%CI [32]. Moreover, data of clinicopathological features was extracted in study available by estimating ORs. The heterogeneity of included studies across the results was assessed by using $\mathrm{I} 2$ statistics and $\mathrm{P}$ value, and if $\mathrm{I}^{2}>50 \%$ or $P<0.1$, the results was considered statistically significant and randomeffects models are employed. If $P \geq 0.1$ and $\mathrm{I}^{2} \leq 50 \%$, fixedeffects models are employed. If the 95\% CI didn't overlap 1 , or $P<0.05$, results would be considered statistically significant. Statistical analyses were performed using Stata 13.0 (Stata Corporation, College Station, TX).

\section{Sensitivity analyses}

We carried out sensitivity analysis, also named influence analysis, to evaluate the effect of single study on the whole results and meanwhile try to find the origin of heterogeneity for each survival outcome group.

\section{Publication bias}

Publication bias was assessed graphically using funnel plots, and funnel plot Symmetry was evaluated by Begg's and Egger's linear regression method ( $p<0.05$ was considered statistically significant publication bias).

\section{ACKNOWLEDGMENTS}

The authors would like to acknowledge all the members of clinical research center of The First Affiliated Hospital of Xi'an Jiaotong University

\section{CONFLICTS OF INTEREST}

The authors declare that they have no conflict of interest.

\section{FUNDING}

This study was supported by grants from National Natural Science Foundation of China (NO.81274136). 


\section{REFERENCES}

1. Siegel RL, Miller KD, Jemal A. Cancer statistics, 2016. CA Cancer J Clin. 2016; 66:7-30.

2. Yang J, Li X, Liu X, Liu Y. The role of tumor-associated macrophages in breast carcinoma invasion and metastasis. Int J Clin Exp Pathol. 2015; 8:6656-64.

3. Su S, Liu Q, Chen J, Chen J, Chen F, He C, Huang D, Wu W, Lin L, Huang W, Zhang J, Cui X, Zheng F, et al. A positive feedback loop between mesenchymal-like cancer cells and macrophages is essential to breast cancer metastasis. Cancer Cell. 2014; 25:605-20.

4. Condeelis J, Pollard JW. Macrophages: obligate partners for tumor cell migration, invasion, and metastasis. Cell. 2006; 124:263-66.

5. Grivennikov SI, Greten FR, Karin M. Immunity, inflammation, and cancer. Cell. 2010; 140:883-99.

6. Wu P, Wu D, Zhao L, Huang L, Chen G, Shen G, Huang $\mathrm{J}$, Chai Y. Inverse role of distinct subsets and distribution of macrophage in lung cancer prognosis: a metaanalysis. Oncotarget. 2016; 7:40451-60. doi: 10.18632/ oncotarget.9625

7. Mantovani A, Allavena P. The interaction of anticancer therapies with tumor-associated macrophages. J Exp Med. 2015; 212:435-45.

8. Biswas SK, Allavena P, Mantovani A. Tumor-associated macrophages: functional diversity, clinical significance, and open questions. Semin Immunopathol. 2013; 35:585-600.

9. Singla RD, Wang J, Singla DK. Regulation of Notch 1 signaling in THP-1 cells enhances M2 macrophage differentiation. Am J Physiol Heart Circ Physiol. 2014; 307:H1634-42.

10. Peng J, Tsang JY, Li D, Niu N, Ho DH, Lau KF, Lui VC, Lamb JR, Chen Y, Tam PK. Inhibition of TGF- $\beta$ signaling in combination with TLR7 ligation re-programs a tumoricidal phenotype in tumor-associated macrophages. Cancer Lett. 2013; 331:239-49.

11. Sica A, Invernizzi P, Mantovani A. Macrophage plasticity and polarization in liver homeostasis and pathology. Hepatology. 2014; 59:2034-42.

12. Zheng G, Ge M, Qiu G, Shu Q and Xu J. Mesenchymal Stromal Cells Affect Disease Outcomes via Macrophage Polarization. Stem cells international. 2015; 2015:989473.

13. Fan QM, Jing YY, Yu GF, Kou XR, Ye F, Gao L, Li R, Zhao QD, Yang Y, Lu ZH, Wei LX. Tumor-associated macrophages promote cancer stem cell-like properties via transforming growth factor-beta1-induced epithelialmesenchymal transition in hepatocellular carcinoma. Cancer Lett. 2014; 352:160-68.

14. Tiainen S, Tumelius R, Rilla K, Hämäläinen K, Tammi M, Tammi R, Kosma VM, Oikari S, Auvinen P. High numbers of macrophages, especially M2-like (CD163-positive), correlate with hyaluronan accumulation and poor outcome in breast cancer. Histopathology. 2015; 66:873-83.
15. Hollmén M, Roudnicky F, Karaman S, Detmar M. Characterization of macrophage - cancer cell crosstalk in estrogen receptor positive and triple-negative breast cancer. Sci Rep. 2015; 5:9188.

16. Goswami KK, Barik S, Banerjee S, Bhowmick AK, Biswas J, Bose A, Baral R. Supraglottic laryngeal tumor microenvironmental factors facilitate STAT3 dependent pro-tumorigenic switch in tumor associated macrophages to render utmost immune evasion. Immunol Lett. 2013; 156:7-17.

17. Buldakov M, Zavyalova M, Krakhmal N, Telegina N, Vtorushin S, Mitrofanova I, Riabov V, Yin S, Song B, Cherdyntseva N, Kzhyshkowska J. CD68, but not stabilin-1 tumor associated macrophages in gaps of ductal tumor structures negatively correlate with the lymphatic metastasis in human breast cancer. Immunobiology. 2015.

18. Medrek C, Pontén F, Jirström K, Leandersson K. The presence of tumor associated macrophages in tumor stroma as a prognostic marker for breast cancer patients. BMC Cancer. 2012; 12:306.

19. Gwak JM, Jang MH, Kim DI, Seo AN, Park SY. Prognostic value of tumor-associated macrophages according to histologic locations and hormone receptor status in breast cancer. PLoS One. 2015; 10:e0125728.

20. Yuan ZY, Luo RZ, Peng RJ, Wang SS, Xue C. High infiltration of tumor-associated macrophages in triplenegative breast cancer is associated with a higher risk of distant metastasis. Onco Targets Ther. 2014; 7:1475-80.

21. Zhang Y, Cheng S, Zhang M, Zhen L, Pang D, Zhang Q, Li Z. High-infiltration of tumor-associated macrophages predicts unfavorable clinical outcome for node-negative breast cancer. PLoS One. 2013; 8:e76147.

22. Schreiber RD, Old LJ, Smyth MJ. Cancer immunoediting: integrating immunity's roles in cancer suppression and promotion. Science. 2011; 331:1565-70.

23. Qian BZ, Pollard JW. Macrophage diversity enhances tumor progression and metastasis. Cell. 2010; 141:39-51.

24. Biswas SK, Mantovani A. Macrophage plasticity and interaction with lymphocyte subsets: cancer as a paradigm. Nat Immunol. 2010; 11:889-96.

25. Sousa S, Brion R, Lintunen M, Kronqvist P, Sandholm J, Mönkkönen J, Kellokumpu-Lehtinen PL, Lauttia S, Tynninen O, Joensuu H, Heymann D, Määttä JA. Human breast cancer cells educate macrophages toward the M2 activation status. Breast Cancer Res. 2015; 17:101.

26. Campbell MJ, Wolf D, Mukhtar RA, Tandon V, Yau C, Au A, Baehner F, van't Veer L, Berry D, Esserman LJ. The prognostic implications of macrophages expressing proliferating cell nuclear antigen in breast cancer depend on immune context. PLoS One. 2013; 8:e79114.

27. Leek RD, Lewis CE, Whitehouse R, Greenall M, Clarke $\mathrm{J}$, Harris AL. Association of macrophage infiltration with angiogenesis and prognosis in invasive breast carcinoma. Cancer Res. 1996; 56:4625-29. 
28. Gottfried E, Kunz-Schughart LA, Weber A, Rehli M, Peuker A, Müller A, Kastenberger M, Brockhoff G, Andreesen R, Kreutz M. Expression of CD68 in non-myeloid cell types. Scand J Immunol. 2008; 67:453-63.

29. Mantovani A, Germano G, Marchesi F, Locatelli M, Biswas SK. Cancer-promoting tumor-associated macrophages: new vistas and open questions. Eur J Immunol. 2011; 41:252225.

30. Hollmén M, Karaman S, Schwager S, Lisibach A, Christiansen AJ, Maksimow M, Varga Z, Jalkanen S, Detmar M. G-CSF regulates macrophage phenotype and associates with poor overall survival in human triple-negative breast cancer. OncoImmunology. 2015; 5:e1115177.
31. Brace MD, Wang J, Petten M, Bullock MJ, Makki F, Trites J, Taylor SM, Hart RD. Differential expression of transforming growth factor-beta in benign vs. papillary thyroid cancer nodules; a potential diagnostic tool? J Otolaryngol Head Neck Surg. 2014; 43:22.

32. Zhang QW, Liu L, Gong CY, Shi HS, Zeng YH, Wang XZ, Zhao YW, Wei YQ. Prognostic significance of tumorassociated macrophages in solid tumor: a meta-analysis of the literature. PLoS One. 2012; 7:e50946. 